\title{
DESIGNING AGRICULTURAL ECONOMICS AND AGRIBUSINESS UNDERGRADUATE PROGRAMS
}

\author{
JEFFREY M. GILLESPIE \\ Market and Trade Economics Division, Economic Research Service, U.S. Department of Agriculture, Washington, DC \\ MARIA BAMPASIDOU* \\ Department of Agricultural Economics and Agribusiness, Louisiana State University, Baton Rouge, Louisiana
}

\begin{abstract}
Agricultural economics and agribusiness (AEAB) programs offer their graduates unique exposure to agricultural markets, policy, and production systems, which differentiates them from business programs. Despite the advantages associated with AEAB degrees, a significant challenge universities and $A E A B$ graduates face is a general lack of recognition of what agricultural economics is and what an agricultural economist does. Using data collected from U.S. 1862 and 1890 land grant universities, we stress the importance of designing effective AEAB curricula based on enrollment trends, the desired attributes of graduates, and the current structure of AEAB undergraduate programs.
\end{abstract}

Keywords. Agribusiness, agricultural economics, curricula, programs, skills

JEL Classifications. A20, A22, Q10

\section{Introduction}

There are numerous advantages to holding an undergraduate degree in agricultural economics or agribusiness. These degrees have value in that they are generally considered to be well balanced in content, result in good starting salaries and potential for upward mobility, and have relatively high employment rates. Carnevale, Strohl, and Melton (2011) showed agricultural economics ${ }^{1}$ graduates to be in the top 10 among graduates of all college majors in terms

\footnotetext{
The authors would like to thank four anonymous referees and the editors for helpful comments and suggestions. Disclaimer: The views expressed are the authors and should not be attributed to the Economic Research Service or the U.S. Department of Agriculture.

*Corresponding author's e-mail: mbampasidou@agcenter.lsu.edu

1 The Carnevale, Strohl, and Melton (2011) and Carnevale, Cheah, and Hanson (2015) studies examined graduates categorized as having majored in agricultural economics. They used data from the American Community Survey through the U.S. Census, which asks respondents to write their major on the survey form. These were then categorized into various broad major categories, with agricultural economics as opposed to agribusiness being the name of the broad major category.
} 
of full-time employment in 2009. At that time, median earnings of agricultural economics graduates were $\$ 60,000$, with food science being the only major traditionally offered by colleges of agriculture with a higher median income. An updated analysis by Carnevale, Cheah, and Hanson (2015) showed median agricultural economics graduate earnings of $\$ 67,000$, which was highest among agriculture majors with $25 \%$ of those holding the degree earning in excess of $\$ 100,000 /$ year. Agricultural economics graduates had higher earnings than general business graduates, with some of the specific fields within business having higher and others having lower earnings. The attribute of agricultural economics and agribusiness (AEAB) graduates that has generally been argued to differentiate them from general business graduates is their expertise in the unique aspects of the agricultural industry.

Despite the advantages associated with AEAB degrees, a significant challenge universities and $\mathrm{AEAB}$ graduates face is a general lack of public recognition of what agricultural economics is and what an agricultural economist does. With smaller percentages of the general population hailing from farms and rural areas, fewer people are likely to be well versed in agriculture (Colbath and Morrish, 2010; Dale, Robinson, and Edwards, 2017). As this trend continues, past experience suggests the challenge of attracting students into AEAB undergraduate programs will continue without significant effort expended to inform the public of the value of these degrees. Furthermore, reduced state support at a number of U.S. universities has caused many universities to carefully examine academic programs to decide which to continue to offer (Oliff et al., 2013).

These issues, as well as the need for academic leaders of all disciplines to routinely evaluate curricula to ensure robust academic programs, led us to ask questions regarding how $\mathrm{AEAB}$ undergraduate programs are structured. How do agricultural economists define the skill set of an agricultural economics or agribusiness graduate? Given the desired skill set, what are some of the issues that need to be considered in structuring undergraduate AEAB degree programs? How do agricultural economics program curricula differ from those of agribusiness programs? We discuss three major issues with regard to AEAB curricula: enrollment trends, the desired attributes of graduates, and the current structure of $A E A B$ undergraduate programs. We focus on undergraduate majors in $\mathrm{AEAB}$, but do not focus on the academic departments in which they reside, per se. ${ }^{2}$

We first use data from the U.S. Department of Agriculture's (USDA) Food and Agricultural Education Information System (FAEIS) database to examine AEAB enrollment trends among 106 state-supported universities with agricultural economics, business, and management programs. Factors that are generally

2 For information on leadership in AEAB departments and the relationship with development of academic programs, the reader is referred to Boland (2009). 
considered as faculty develop or revise curricula are then discussed. This discussion is based on previous literature and our observations working with curricula. We then use previous literature to discuss what agricultural economists are training students to do and the attributes agribusiness employers indicate they desire in AEAB graduates. The structures of AEAB programs from throughout the United States are then analyzed. This analysis is based on examination of AEAB programs at all U.S. 1862 and 1890 land grant universities that offer AEAB bachelor's degrees. ${ }^{3}$ Bachelor's degrees in agriculture with agribusiness or agricultural economics areas of concentration are not included, nor are bachelor's degrees in natural resource economics, environmental economics, or similar variants. ${ }^{4}$ Degree names, areas of concentration, and percentages of the programs requiring specific courses are examined. Finally, general observations about $\mathrm{AEAB}$ programs are made, including what is being emphasized and what we believe needs further consideration in the future.

\section{Notable Trends}

A number of trends are noteworthy for AEAB curricula. Heiman et al. (2002) and Perry (2010) discuss the general shift from agricultural economics to agribusiness programs over the past 40 years, which resulted largely from both student and employer demands. As U.S. farms have decreased in number and grown in size, fewer graduates have been returning to or entering farming. Simultaneously, as (1) greater value has been added to food products to make them more convenient for home preparation, (2) food products have become less "locally sourced," and (3) year-round supplies of fresh fruits and vegetables have become available via greater international trade, post-farm gate agricultural business has gained economic importance. The farmer's share of the market basket provides a means to illustrate the importance of post-farm gate agricultural business in converting raw agricultural commodities to products consumers may purchase in the grocery store. In 2015, the farmer's share of the market basket for food items averaged 16\% (USDA, Economic Research Service, 2016), suggesting that \$0.84 of every dollar spent for these food products went to post-farm gate agricultural enterprises.

A result of these trends is that traditional agricultural economics programs that used to focus more heavily on farm management and farm-level marketing

3 We examined land grant universities assuming they would be representative of AEAB programs. It is recognized that there are a number of $A E A B$ programs at non-land grant universities, as analyzed previously by Boland and Akridge (2008b), some of which are quite large, such as Cal Poly, San Luis Obispo.

4 Some universities offer bachelor's degrees in agriculture with areas of concentration in AEAB, and in some cases those programs are similar to curricula for AEAB majors. We do not assume, however, that such programs would necessarily provide the full set of coursework expected of AEAB majors. Thus, these programs are not included in our analysis. 
have gradually shifted emphasis toward post-farm gate agricultural business. ${ }^{5}$ Furthermore, because of the global and more vertically coordinated nature of today's agricultural industry, today's farmer needs a better understanding of the agribusiness supply chain than did previous generations of farmers. Related to the shift in programs from agricultural economics to agribusiness, Larson (1996) discusses the greater curricular emphasis being placed on written and oral communication skills, economics, and business. Graduates need these skills to compete in post-farm gate, often large-scale multinational agribusiness firms. Larson (1996) also discusses the lower emphasis being placed on technical agriculture in AEAB programs. Boland and Akridge (2008b) discuss some of the differences between AEAB curricula. Furthermore, Boland and Akridge (2004) discuss how agribusiness programs need to further define themselves as differentiated from traditional agricultural economics programs.

\subsection{Enrollment Trends in Agricultural Economics and Agribusiness Undergraduate Programs}

U.S. AEAB undergraduate programs have experienced increased enrollment over the past 10 years. Of the 106 U.S. state universities that included agricultural economics, business, and management programs, fall enrollment increased by $27 \%$ from 2004 to 2013 (USDA, 2016). ${ }^{6}$ In contrast, over this period total fall enrollment of all undergraduates enrolled in degree-granting postsecondary institutions in the United States increased by $18 \%$ (National Center for Education Statistics, 2014), showing the growth rate for AEAB programs to have been greater than that for undergraduate programs in general. Because of incomplete data and problems associated with separating out agricultural economics enrollment from agribusiness enrollment at universities that include both, it is difficult to develop a full picture of enrollment by agricultural economics versus agribusiness programs. However, of 20 land grant university agribusiness programs for which we have full data sets from our survey of $\mathrm{AEAB}$ programs, the increase in enrollment was $45 \%$. For the five agricultural economics programs for which we have full data sets, the increase was $17 \%$. Increased enrollment follows a number of years of declining enrollment in these programs during the 1980s (Adrian, 1990), followed by the 1990s when decreased enrollment in agricultural economics programs was more than offset by increased enrollment in agribusiness programs (Heiman et al., 2002).

5 Boland and Akridge (2004) noted, however, that many undergraduate agribusiness programs are based on traditional agricultural economics curricula with a wide variety of courses that do not necessarily make up a cohesive agribusiness curriculum.

6 There were 109 programs listed in FAEIS for 2015. A number of programs had no data entered for 2015. We visited the websites of those universities and found three that had no AEAB program listed. 


\section{What Is Generally Considered as Faculty Develop or Revise Undergraduate Programs?}

In examining $A E A B$ curriculum structure, it is helpful to first understand what faculty consider when structuring undergraduate programs. Wysocki et al. (2003) discussed how student exit interviews, discussion with graduates and agricultural industry leaders, faculty insight, and/or job recruiters were used in curriculum revisions at three universities. Based primarily on our experience on undergraduate committees, we separate the factors affecting how curriculum decisions are made into two categories: those that originate from within academia (internal factors) and those that originate from outside of academia (external factors).

One internal factor is the desired attributes generally held for college graduates, which we observe usually includes strong analytical skills and broad exposure to the natural sciences, arts, humanities, and social sciences; good communication skills; and major-specific content. The AEAB students at most colleges and universities develop these skills through general education courses in a range of areas, plus specific analytical skills gained through disciplinary courses. A second internal factor, observed student strengths and weaknesses, typically involves faculty identifying student strengths and weaknesses via classroom observation and extracurricular activities. ${ }^{7}$ Noted deficiencies in certain areas may lead to a requirement for additional coursework ${ }^{8}$ or the imposition of prerequisite course requirements.

A third internal factor, institutional factors and perspectives of faculty, involves the unique perspectives faculty hold regarding how a curriculum should be structured, often the result of previous experiences from other universities. Faculty may hear from colleagues, "This is how it was done at XYZ University," perhaps a program for which they had previous student or faculty experience. A fourth internal factor is evaluation of peer programs, on which a number of studies have reported (Boland and Akridge, 2008b; Harris, Miller, and Wells, 2003; Larson, 1996; Litzenberg, Gorman, and Schneider, 1983). The question here is, what is the generally expected training of an individual with a degree in this field? The importance of this factor is twofold, ensuring graduate competitiveness in the labor market and developing strong program branding. Finally, another internal factor is student input.

External factors considered in structuring undergraduate programs include: (1) employer feedback, (2) regional employment opportunities, and (3) alumni perceptions. Employer feedback helps in identifying the strengths and weaknesses of graduates. Employers may also provide insight on current professional needs

7 For some cases, this factor could also be argued to be an external factor, such as cases where intern employers provide formal feedback on student performance.

8 An example would be the introduction of a spreadsheet-use class or seminar to prepare students for junior- and senior-level classes. 
and how curricula may be altered to meet those needs. Regional employment opportunities should be considered. For example, programs in a region with significant food processing might offer specific coursework addressing the needs of that segment. Industry perspectives were discussed by Boland and Akridge (2004). Finally, alumni perceptions can provide valuable information on how well AEAB programs prepare them for the workforce or for future studies (Hamilton et al., 2016). We focus on two internal factors, the desired attributes of college graduates and evaluation of peer programs, and one external factor, employer feedback.

\section{Desired Attributes of College Graduates and Employer Feedback}

A broad objective of undergraduate programs is to train students to be wellinformed citizens so they can make better-informed decisions. ${ }^{9}$ At most U.S. universities, this involves students taking an array of general education courses that expose them to broad perspectives in the arts, humanities, natural sciences, analytics, and social sciences. Furthermore, most undergraduate programs are designed to prepare majors for the job market. To this end, AEAB majors take courses leading to understanding of specific concepts in business and economics as they relate to agriculture. Generally, AEAB programs are designed to produce graduates who can perform as agricultural business professionals in management positions in agribusiness firms; retail, wholesale, or commodity marketing; finance and banking; rural land appraisal and real estate; and production agriculture. Graduates should be able to contribute as government and publicsector employees, particularly in analyzing markets and policy. More advanced students should be able to successfully pursue graduate study in agricultural economics. Carnevale, Strohl, and Melton (2011) showed agricultural economics graduates to be employed in the following industries: financial services $(21 \%)$, agriculture $(11 \%)$, retail trade $(8 \%)$, public administration $(8 \%)$, and wholesale trade in durables $(7 \%)$, followed by a variety of other industries; and in the following occupations: management $(36 \%)$, sales $(21 \%)$, finance $(11 \%)$, office $(6 \%)$, and business $(3 \%)$.

The National Food and Agribusiness Management Education Commission (NFAMEC) (2004) provided results of a survey of agricultural businesses, ranking 16 skills, abilities, and experiences sought by agribusiness managers in new hires. A separate survey of 137 agricultural business employers conducted by Noel and Qenani (2013) allowed for conjoint analysis of the most important attributes of $\mathrm{AEAB}$ graduates. Results of these studies are summarized in Table 1.

9 For example, the Louisiana State University (2017) “2020 Flagship Agenda Goals” for learning includes the following: "Enhance a faculty-led and student-centered learning environment that develops engaged citizens and enlightened leaders." It then goes on to list critical thinking, communication, and problem-solving as skills; and civic and intellectual leadership as attributes of graduates. 
Table 1. Ranking of Attributes of New Hires by Agribusiness Employers, Results of Two Studies

\begin{tabular}{|c|c|c|c|}
\hline \multicolumn{2}{|c|}{$\begin{array}{l}\text { National Food and Agribusiness } \\
\text { Management Commission (2004) Ranking of } \\
\text { Skills, Abilities, and Experiences } \\
\text { Sought in New Hires }\end{array}$} & \multicolumn{2}{|c|}{$\begin{array}{l}\text { Noel and Qenani (2013) } \\
\text { Ranking of Attributes of } \\
\text { Agricultural Economics and } \\
\text { Agribusiness Graduates }\end{array}$} \\
\hline Rank & Skill, Ability, or Experience & Rank & Attribute \\
\hline 1 & Interpersonal communication skills & 1 & Creativity \\
\hline 2 & Critical thinking skills & 2 & Communication skills \\
\hline 3 & Writing skills & 3 & Critical thinking skills \\
\hline 4 & Computer skills & 4 & Teamwork skills \\
\hline 5 & Culture/gender awareness/sensitivity & 5 & Knowledge of marketing \\
\hline 6 & Quantitative analysis skills & 6 & Knowledge of finance \\
\hline 7 & Knowledge of general business management & & \\
\hline 7 (tie) & Oral presentation skills & & \\
\hline 9 & Knowledge of the food/agribusiness markets & & \\
\hline 10 & Knowledge of accounting and finance & & \\
\hline 11 & Intern/co-op experience & & \\
\hline 12 & Knowledge of macroeconomics, trade, etc. & & \\
\hline 13 & Broad-based knowledge in the liberal arts & & \\
\hline 13 (tie) & International experience & & \\
\hline 15 & Foreign language & & \\
\hline 16 & Production agriculture experience & & \\
\hline
\end{tabular}

Several attributes of graduates stand out from both surveys as particularly important to employers. First, communication skills are among the most important, with (1) interpersonal communication skills and writing skills ranking in the top 3 in the NFAMEC (2004) study, (2) oral presentation skills tied for seventh (in the top half), and (3) communication skills ranking second in the Noel and Qenani (2013) study. Earlier, Litzenberg and Schneider (1987) found communication skills to be highly important to agribusiness employers, ranked second of six attributes. Second, critical thinking is a sought-after attribute, with critical thinking skills ranked second in the NFAMEC (2004) study and third in the Noel and Qenani (2013) study. Other nonanalytical skills ranking in the top half in both studies included cultural/gender awareness/sensitivity in the NFAMEC (2004) study and creativity, which ranked first in the Noel and Qenani (2013) study.

Knowledge of marketing, finance, accounting, and economics, as well as experience in production agriculture, tended to rank in the lower half of the factors. These skills tended to rank lower than interpersonal characteristics and communications skills in the Litzenberg and Schneider (1987) study, as well. Overall, so-called soft skills such as interpersonal skills, verbal and written communication, and critical thinking skills tend to be ranked more highly by employers relative to major-specific skills or technical knowledge 
related to the job. ${ }^{10}$ These results should be kept in mind when developing curricula, but we caution against developing curricula based only on industry perspectives. ${ }^{11}$

\section{How Do Universities Name Agricultural Economics and Agribusiness Programs?}

The name of a program is associated with its curriculum and thus communicates the graduate's area of expertise. We examined the AEAB curricula of all U.S. 1862 and 1890 land grant universities, identifying 58 undergraduate programs that we categorized as AEAB programs. This was conducted by examining the websites of each of these universities during July-September 2015. In total, 69 (51 [1862] and 18 [1890]) land grant universities were examined, of which 44 offered bachelor's degrees in AEAB. Some universities included more than one such program and, in some cases, both agribusiness and agricultural economics programs. If the program name included "economics" and "agricultural" or "food" but not "business," then the program was categorized as an agricultural economics program. If the program name included "business," "marketing," or "management" and "agricultural," "food," or "farm," but not "economics," then the program was categorized as an agribusiness program. If the program name included "economics" and "agricultural" and "business" or "management," then the program was categorized as a hybrid agricultural economics/agribusiness program. Table 2 shows the universities with programs in each category. In total, 17 agricultural economics programs, 35 agribusiness programs, and 6 hybrid AEAB programs were identified. Twenty-five 1862 and 1890 land grant universities did not offer AEAB majors (Table 2). Some of these offered bachelor of science degrees in agriculture or agricultural science with concentrations or plan of study in agricultural economics or agribusiness, and some offered bachelor's degrees in resource and/or environmental economics. The latter did not concentrate on the agricultural/agribusiness sector, so they were not included. ${ }^{12}$

10 Identification and assessment of desirable employer skills is extensively investigated from program coordinators, college administrators, and student affairs offices among other entities in an effort to provide a gratifying undergraduate experience and produce well-rounded graduates. It is not the scope of this article to address that aspect in detail, but we can see a similar ranking of skills for nonagriculture majors. Refer to the National Association of Colleges and Employers (2016) “Job Outlook.”

11 Another strand of literature examines student perspectives regarding skills acquired throughout their undergraduate studies. We do not address that in this article. Suggested readings include Riesenberg (1988) and Smith (1989) for a discussion related to college of agriculture graduates. Scanlon, Bruening, and Cordero (1996), Graham (2001), and Bampasidou et al. (2016) include case studies of agricultural education and agricultural economics program graduates, respectively.

12 Boland, Lehman, and Stroade (2001) discuss the differentiation between a formal degree in agribusiness (BSABM) and a degree in agriculture with a major in agribusiness (BSA). In our analysis, we consider a major in $\mathrm{AEAB}$ regardless of whether the bachelor of science degree is in $\mathrm{AEAB}$ or agriculture. 
Table 2. U.S. 1862 and 1890 Land Grant Universities Including the Following Agricultural Economics and Agribusiness Majors

\begin{tabular}{|c|c|c|c|}
\hline Agricultural Business Major & Agricultural Economics Major & $\begin{array}{l}\text { "Hybrid" Agricultural Economics } \\
\text { and Agribusiness Major }\end{array}$ & $\begin{array}{l}\text { No Agricultural Economics } \\
\text { or Agribusiness Major }\end{array}$ \\
\hline Clemson University & Fort Valley State University & Auburn University & Alabama A\&M University \\
\hline Colorado State University & Kansas State University & Cornell University & Alcorn State University \\
\hline Florida A\&M University & North Dakota State University & New Mexico State University & Delaware State University \\
\hline Iowa State University & Oklahoma State University & Ohio State University & Kentucky State University \\
\hline Kansas State University & Purdue University & University of Arizona & Langston University \\
\hline Lincoln University & South Dakota State University & Washington State University & North Carolina A\&T \\
\hline Louisiana State University & Texas A\&M University & & Prairie View A\&M \\
\hline Maryland-Eastern Shore & University of Florida & & Rutgers University \\
\hline Michigan State University & University of Georgia & & Southern University \\
\hline Mississippi State University & University of Idaho & & Tennessee State University \\
\hline Montana State University & University of Illinois & & Tuskegee University \\
\hline North Carolina State University & University of Kentucky & & University of Alaska \\
\hline North Dakota State University & University of Maryland & & University of Arkansas Pine Bluff \\
\hline Oklahoma State University & University of Missouri & & University of California Berkeley \\
\hline Oregon State University & University of Nebraska & & University of California Davis \\
\hline Pennsylvania State University & University of Wisconsin & & University of Connecticut \\
\hline
\end{tabular}




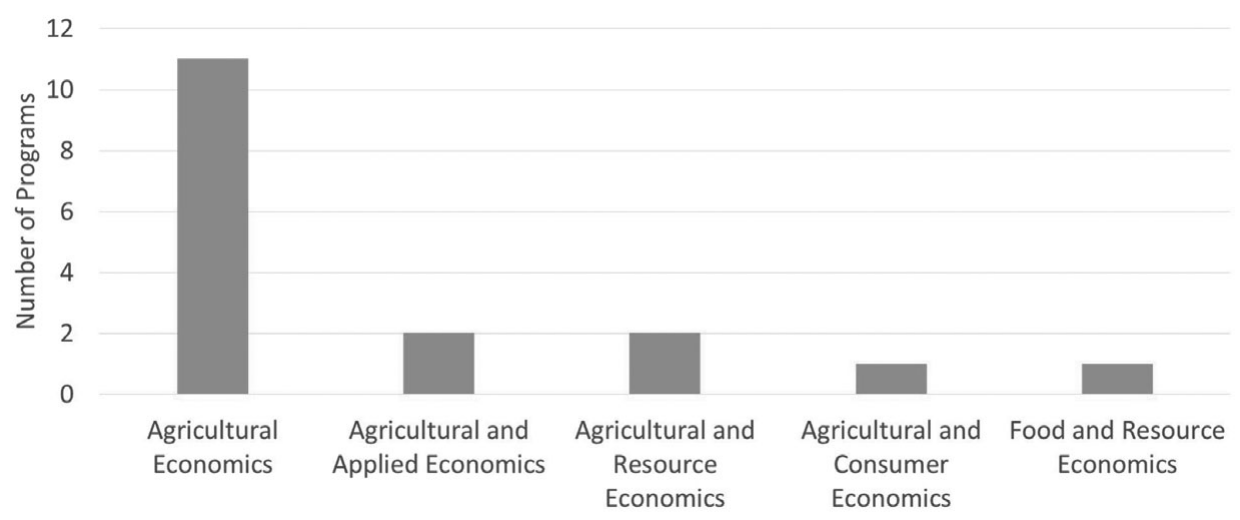

Figure 1. Names of U.S. Agricultural Economics Bachelor's Degree Programs $(\mathrm{n}=17)$

\subsection{Names of AEAB Degree Programs and Enrollment}

Of the 17 agricultural economics bachelor of science degree programs, 11 were named "agricultural economics" (Figure 1). Of the remaining six, two each were named "agricultural and applied economics" and "agricultural and resource economics," and one each was named "agricultural and consumer economics" and "food and resource economics." Though most of these programs continue to retain the traditional "agricultural economics" name, others have extended or altered their names to indicate greater specialization in a particular area and/or to attract students who would be less interested in a traditional agricultural economics degree. The adjectives "applied," "resource," "consumer," and "food" imply a program that may appeal to a more urban, less farm-oriented student population. Of the 17 programs, we identified 5 for which there were no other competing programs such as an agribusiness program on the same campus, as can be identified via Table 2 . Of these five, the average 2013 enrollment was 213.

Of the 35 agribusiness bachelor of science degree programs, 14 were named "agribusiness" and 8 were named "agricultural business," so the majority incorporated solely the words "agriculture" and "business" into their degree names (Figure 2). An additional seven were named either "agribusiness management" or "agricultural business management," emphasizing the managerial aspects of agricultural business. Six additional program names are shown in Figure 2, which incorporate the words "rural development," "food," "farm management," "food industry," "marketing," and/or "administration."

Of the 35 programs, 20 were identified for which there were no other competing programs such as an agricultural economics program on the same campus, as can be identified via Table 2. Of these, the average 2013 enrollment was 143 . Of the 12 named "agribusiness" or "agricultural business" (Arkansas, 


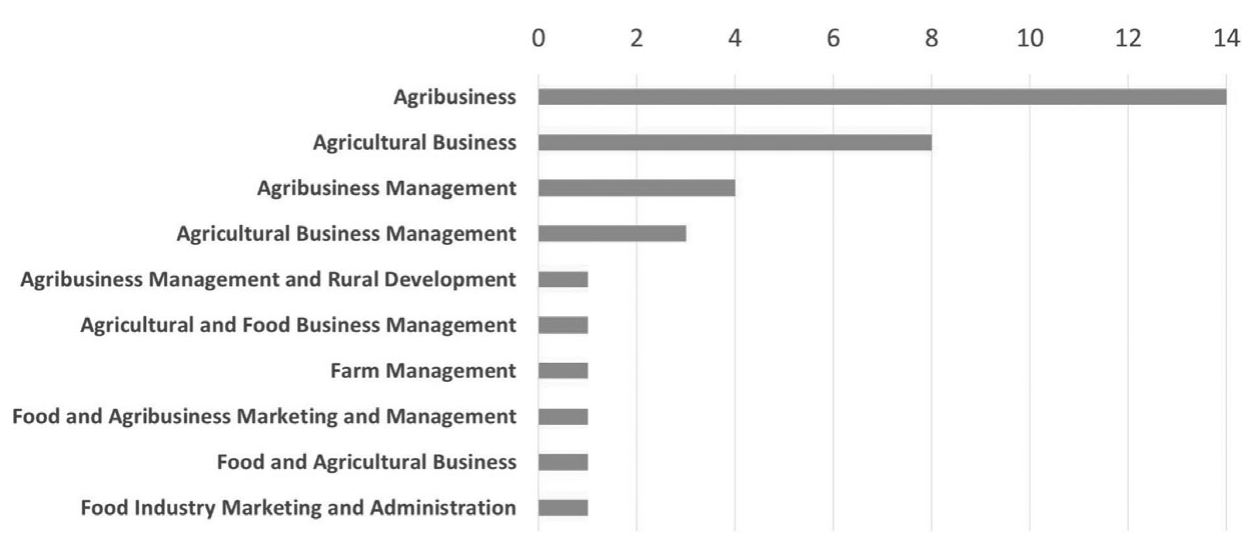

Figure 2. Numbers of U.S. Agricultural Business Bachelor's Degree Programs by Name $(\mathrm{n}=35)$

Colorado State, Florida A\&M, Iowa State, Louisiana State, Maryland-Eastern Shore, Mississippi State, Lincoln, Montana State, Clemson, South Carolina State, and Virginia Tech), the average enrollment was 133. Of the remaining eight, average enrollment was 161 . Although those including additional words other than "agricultural business" or "agribusiness" in the degree name had numerically higher enrollment, there is little evidence to suggest that, on a global scale, more additional adjectives in the degree name significantly affected enrollment. Any such impacts are likely to be university or state specific in nature.

The remaining six hybrid programs were named "agribusiness and applied economics," "agricultural business and economics," "agricultural and food business economics," "agricultural economics and agricultural business," "agricultural economics and management," and "applied economics and management." The average enrollment for these six programs in 2013 was 289 .

In total, of the 58 AEAB programs, $33(57 \%)$ had traditional agricultural economics, agricultural business, or agribusiness names, whereas the remaining $43 \%$ had names that varied in many cases significantly from these. The average agricultural economics and hybrid program enrollments were numerically greater than the average agribusiness enrollments, but the sample sizes for agricultural economics and hybrid programs were small, so more work should be done with a fuller set of data (including non-land grant universities) to discern whether true enrollment differences exist. Although using a degree program name other than one of the traditional disciplinary names allows a program to differentiate itself and perhaps attract nontraditional students, a downside could be that general name recognition of the greater AEAB field is reduced with the array of program names. 


\subsection{Areas of Concentration}

A rather large number of areas of concentration are offered within AEAB programs at land grant universities, with 66 different area-of-concentration names and a total of 88 areas of concentration offered, for an average of 1.6 areas of concentration offered per program. Using the term "area of concentration," we refer to specific designated and approved curricular areas within $\mathrm{AEAB}$ through which $\mathrm{AEAB}$ majors may formally concentrate their coursework beyond the base $A E A B$ requirements. We do not examine minors, which refer to formal, concentrated study of fields outside of the AEAB major (e.g., agronomy, sociology, etc.). Thirty-eight percent of the programs offered areas of concentration, where some programs offer rather large numbers of areas of concentration (one program offers 15). Table 3 provides all of the area-of-concentration names, and Figure 3 provides a breakdown by general area. The most common areas of concentration were management oriented, with 11 in the agribusiness management/management category and 9 in the farm/ranch management category. An additional four were in the agribusiness management and marketing category. Areas of concentration emphasizing marketing were the second-most common, with eight programs offering agricultural/food/commodity marketing areas of concentration, plus an additional four offering agribusiness management and marketing areas of concentration. Eight programs each offered agricultural finance/finance and/or international trade/business/development areas of concentration. Other areas of concentration that appeared to hold promise for attracting nontraditional AEAB students were pre-law, pre-vet, and quantitative skills/analysis/theory.

\section{Course Requirements}

During the examination of websites of all U.S. 1862 and 1890 land grant university $A E A B$ programs, course requirements for AEAB undergraduate programs were determined. Course names, course descriptions, and syllabi were used to determine whether required courses fit under specific categories, such as agricultural marketing, agribusiness management, agribusiness finance, and so forth. Categorizing courses presents challenges because course content in a particular program may be delivered via courses with names other than initially expected. However, with sufficient examination of course descriptions and syllabi, courses could generally be categorized into specific course types.

The purpose of this work is to determine which courses are generally considered core to AEAB and the frequency at which other courses are required. We are aware of several previous studies that have conducted such "inventories" of course requirements for AEAB programs (Boland and Akridge, 2008b; Boland, Lehman, and Stroade, 2001; Harris, Miller, and Wells, 2003; Larson, 1996; Litzenberg, Gorman, and Schneider, 1983) but are unaware 
Table 3. Listing of 66 Areas of Concentration in U.S. Land Grant Agricultural Economics and Agribusiness Programs, 58 Programs

\begin{tabular}{|c|c|}
\hline \multicolumn{2}{|c|}{ Areas of Concentration } \\
\hline Accounting & Food Industry \\
\hline Agribusiness Finance & Food Industry Management \\
\hline Agribusiness Management (5) & Food Marketing \\
\hline Agribusiness Management \& Food Marketing & Food Marketing Systems \\
\hline Agribusiness Management \& Marketing & International \\
\hline Agribusiness Markets \& Management & International Agricultural Business \\
\hline Agricultural Accounting & International Business \\
\hline Agricultural Chemical Sales & International Development \\
\hline Agricultural Communications & International Food \& Resource Economics \\
\hline Agricultural Economics (3) & International Marketing \\
\hline Agricultural Finance & International Trade \& Development \\
\hline Agricultural Marketing & Management (4) \\
\hline Agricultural Records/Financial Controls & Marketing (2) \\
\hline Agricultural Systems & Marketing, Sales \\
\hline Applied Agricultural Economics & Natural Resources \\
\hline Applied Economics & Natural Resource Management \\
\hline Biological Systems/Business Management & Policy \\
\hline Commodity Marketing (2) & Policy \& Economic Analysis \\
\hline Computer Applications/Data Management & Policy, International Trade, \& Development \\
\hline Consumer Economics \& Finance & Pre-Law (4) \\
\hline Crop \& Soil Sciences & Pre-Vet \\
\hline Entrepreneurship (2) & Pre-Vet Business \\
\hline Environmental Economics & Pre-Vet Business Management \\
\hline Environmental Economics \& Management & Production \\
\hline Environmental, Energy, \& Resource Economics & Public Policy \\
\hline Farm and Ranch Management (5) & Public Policy \& Law \\
\hline Farm Business Management & Quantitative \\
\hline Farm Management (2) & Quantitative Analysis \\
\hline Finance (2) & Quantitative Skills/Theory \\
\hline Finance and Real Estate & Ranch Business Management \\
\hline Finance in Agribusiness (2) & Rural Development \\
\hline Financial Planning & Rural Entrepreneurship \\
\hline Food \& Agribusiness Marketing \& Management & Strategy \\
\hline
\end{tabular}

of any such studies that have been conducted during the past 13 years. We provide percentages of both $\mathrm{AEAB}$ programs that have required each of the courses. Boland and Akridge (2008b) provided similar statistics, but their counts differ from ours in that they (1) did not limit their sample to land grant university programs and (2) counted within the agricultural economics category bachelor's programs including "agribusiness majors, options, or specializations within another degree." In most cases, these were bachelor of science degrees in agriculture. Table 4 presents the courses required by undergraduate AEAB programs. In this list, because there are many specialized courses that are required at some universities, we include only courses that were required by $\geq 4 \%$ of 


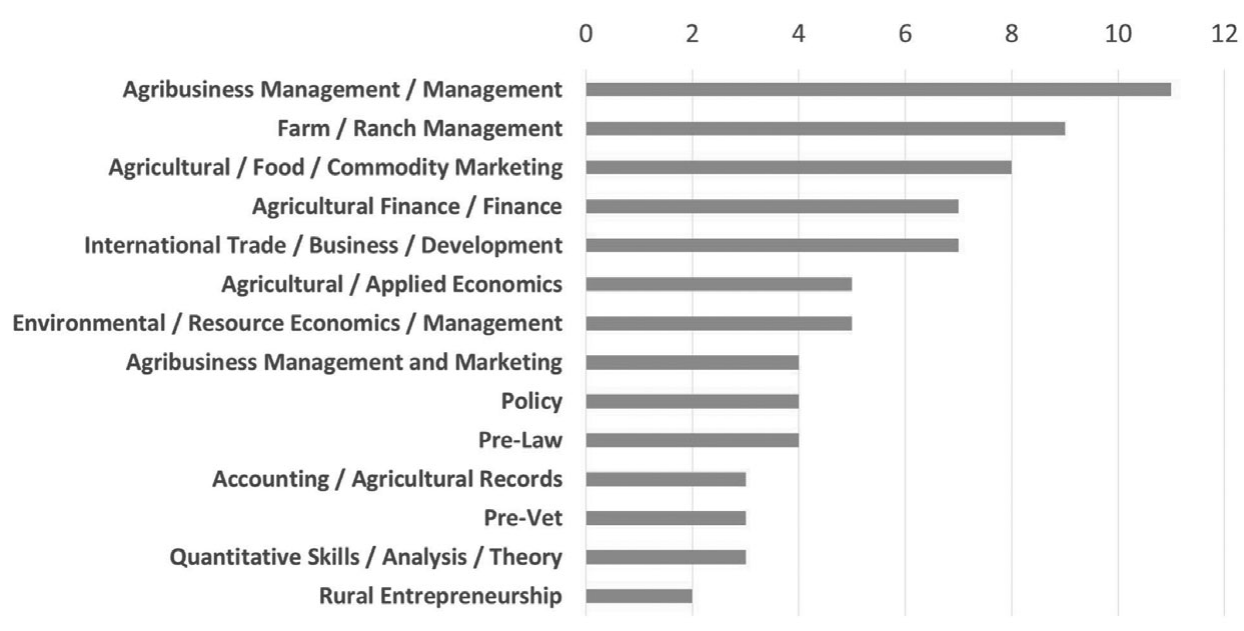

Figure 3. Numbers of Programs Offering Various Areas of Concentration

all AEAB programs. We do not examine elective courses; we examine only those that are required in the major. To test whether there were differences in course requirements by major, we use the testing procedure provided by $\mathrm{Zar}$ (1984, pp. 395-97), which approximates the difference between two proportions assuming a normal distribution.

\subsection{Economics Courses}

All programs required a principles of microeconomics course. Names of these courses varied, from Principles of Microeconomics to Introduction to Agricultural Economics, and so forth, but examination of course descriptions suggests that all programs included a course devoted to introductory microeconomic theory. ${ }^{13}$ All agricultural economics programs also required a principles of macroeconomics course, but $91 \%$ of the agribusiness programs required such a course. If a $P \leq 0.10$ level of significance is required to consider these percentages statistically different, there is insufficient evidence to conclude a difference. Overall, $95 \%$ of the programs required an introductory macroeconomics course. Some of the remaining 5\% of programs include introductory macroeconomics content within other courses but do not require a course specifically devoted to the subject.

The AEAB curricula were less likely to require intermediate microeconomic theory. Seventy-one percent of the programs required intermediate microeconomics, with $69 \%$ of agribusiness and $82 \%$ of agricultural economics programs requiring such a course. If one combines Intermediate Microeconomics,

13 In cases where an Introduction to Agricultural Economics course is offered, these courses may serve as service courses for other curricula. 
Table 4. Percentages of Programs Requiring Specific Courses ${ }^{a}$

\begin{tabular}{|c|c|c|c|}
\hline Course & $\begin{array}{l}\text { Agricultural } \\
\text { Business, } \\
\mathrm{n}=35\end{array}$ & $\begin{array}{l}\text { Agricultural } \\
\text { Economics, } \\
\mathrm{n}=17\end{array}$ & $\begin{array}{l}\text { All } \\
\text { Programs, } \\
\mathrm{n}=58\end{array}$ \\
\hline \multicolumn{4}{|l|}{ Economic theory courses } \\
\hline Principles of Microeconomics & 100 & 100 & 100 \\
\hline Principles of Macroeconomics & 91 & 100 & 95 \\
\hline Other Introductory Economics Course & 11 & 12 & 9 \\
\hline Intermediate Microeconomics & 74 & 82 & 71 \\
\hline Intermediate Macroeconomics & 40 & 59 & 43 \\
\hline Production Economics & 8 & 12 & 10 \\
\hline Managerial Economics & 14 & 0 & 7 \\
\hline Intermediate Micro, Production, or Managerial Econ & 77 & 88 & 82 \\
\hline \multicolumn{4}{|l|}{ Agribusiness courses } \\
\hline Introduction to Agribusiness or Business & 49 & 29 & 38 \\
\hline Designated Agric Econ or Agribus Capstone Course & 9 & 18 & 10 \\
\hline Other Agribusiness Courses ${ }^{\mathrm{b}}$ & 29 & 12 & 21 \\
\hline \multicolumn{4}{|l|}{ Mathematics, quantitative, and computing courses } \\
\hline Calculus I & 88 & 94 & 91 \\
\hline Calculus II & 9 & 24 & 12 \\
\hline Statistics & 91 & 100 & 93 \\
\hline Quantitative Methods in Agricultural Economics & 54 & 41 & 45 \\
\hline Econometrics & 17 & 24 & 21 \\
\hline Any Quantitative Methods Course & 60 & 53 & 55 \\
\hline Any Software Course & 29 & 12 & 24 \\
\hline \multicolumn{4}{|l|}{ Policy, trade, and law courses } \\
\hline Agricultural Trade & 9 & 12 & 9 \\
\hline Agricultural Policy & 34 & 35 & 34 \\
\hline Agricultural Policy and Trade & 9 & 0 & 7 \\
\hline Any Ag Policy, Trade, or International Econ Course & 51 & 41 & 50 \\
\hline Business Law** & 29 & 0 & 19 \\
\hline Agricultural Law* & 31 & 6 & 22 \\
\hline Any Business and/or Agricultural Law Course*** & 60 & 6 & 41 \\
\hline \multicolumn{4}{|l|}{ Accounting and finance courses } \\
\hline Accounting I & 94 & 88 & 93 \\
\hline Accounting II & 51 & 58 & 52 \\
\hline Agribusiness Finance & 26 & 18 & 24 \\
\hline Agricultural Finance & 40 & 18 & 31 \\
\hline Financial Management & 11 & 0 & 9 \\
\hline Finance (Business School) & 20 & 0 & 15 \\
\hline Any Finance Course ${ }^{* * *}$ & 85 & 35 & 71 \\
\hline \multicolumn{4}{|l|}{ Management courses } \\
\hline Management (Business School)* & 29 & 6 & 22 \\
\hline Agribusiness Management** & 63 & 35 & 55 \\
\hline Farm Management** & 40 & 12 & 31 \\
\hline Strategic Management & 6 & 6 & 7 \\
\hline Supply Chain Management & 11 & 0 & 7 \\
\hline Any Management Course*** & 91 & 53 & 81 \\
\hline
\end{tabular}


Table 4. Continued

\begin{tabular}{llll}
\hline \hline & $\begin{array}{l}\text { Agricultural } \\
\text { Business, }\end{array}$ & $\begin{array}{l}\text { Agricultural } \\
\text { Economics, } \\
\mathrm{n}=35\end{array}$ & $\begin{array}{l}\text { All } \\
\text { Programs, }\end{array}$ \\
Course & & & $\mathrm{n}=58$ \\
\hline Marketing and prices courses & 23 & 12 & 22 \\
Agricultural Prices & 77 & 65 & 67 \\
Agricultural Marketing & 20 & 6 & 17 \\
Agribusiness Marketing & 34 & 6 & 26 \\
Marketing (Business School)** & 6 & 34 & 25 \\
Agricultural Market Structure & 11 & 0 & 7 \\
Commodity Marketing & 97 & 71 & 7 \\
Any Marketing Course* & & 6 & 7 \\
Other courses & 6 & 6 & 21 \\
Any Development Economics Course & 9 & 29 & 26 \\
Environmental Economics & 14 & 35 & 57 \\
Resource Economics & 20 & 53 & 50 \\
Any Resource or Environmental Economics Course & 63 & 41 & 58 \\
Any Professional Writing Course & 57 & 53 & \\
Public Speaking/Communications Course & 63 & & 7 \\
Technical Agriculture Course(s) & & & \\
\hline \hline
\end{tabular}

a Asterisks $\left({ }^{* *},{ }^{* *}\right.$, and $\left.{ }^{*}\right)$ indicate the differences at the $P \leq 0.01,0.05$, and 0.10 levels, respectively, between the agricultural business and agricultural economics percentages.

${ }^{\mathrm{b}}$ Courses include Agribusiness Entrepreneurship; Case Studies; Agribusiness Communications; Food Manufacturing, Distribution, and Retailing; Issues in Food and Agricultural Systems; Sales; Survey of Business; Agribusiness Strategy; Business Ethics; and Senior Project.

Production Economics, and Managerial Economics courses into one category, then $82 \%$ of all programs required such a course, including $77 \%$ of agribusiness programs and $88 \%$ of agricultural economics programs. Fewer $(43 \%)$ required an intermediate macroeconomics course, with $40 \%$ of the agribusiness and $59 \%$ of the agricultural economics programs requiring such a course. It appears the $\mathrm{AEAB}$ profession is in agreement that introductory microeconomic and macroeconomic theory are core to the curriculum and most consider intermediate microeconomic theory as core. There appears, however, to be disagreement as to whether intermediate macroeconomic theory is core.

\subsection{Agribusiness Courses}

We designate courses as agribusiness courses if they deal with general business concepts but are not specific to economics, management, marketing, finance, accounting, or quantitative methods. Thirty-eight percent of the programs required an Introduction to Agribusiness or an Introduction to Business course: $49 \%$ of agribusiness and $29 \%$ of agricultural economics programs. Ten percent included a designated agricultural economics or agribusiness capstone course: $9 \%$ of agribusiness and $18 \%$ of agricultural economics programs. Other agribusiness courses including such topics as entrepreneurship, case studies, 
agribusiness strategy, and/or business ethics, and so forth, were also required by $21 \%$ of the programs, including $12 \%$ of agricultural economics and $29 \%$ of agribusiness programs.

\subsection{Mathematics, Quantitative Methods, and Computing Courses}

Ninety-one percent of the AEAB programs required a calculus course, and $12 \%$ required a second calculus course. Although the percentages of agricultural economics curricula requiring these courses were numerically higher than for agribusiness curricula, the differences were not statistically significant, lending insufficient evidence to conclude a difference in calculus requirements. The percentage of curricula requiring calculus is higher than found by Boland and Akridge (2008b), where just over $50 \%$ of the curricula were found to be requiring calculus. This difference could reflect a change in requirements. Note also that in their study, non-land grant programs and bachelor of science degrees in agriculture with $\mathrm{AEAB}$ concentrations were included. Background in calculus is particularly important for some upper division courses, such as intermediate microeconomics. Almost all (93\%) programs required a statistics course.

Forty-five percent of the programs required a course with the name Quantitative Methods in Agricultural Economics or a close name variant, 21\% required an econometrics course, and $55 \%$ required any type of quantitative methods course (which would include either or both Quantitative Methods in Agricultural Economics and econometrics courses). Courses in the former category typically included some econometrics, linear programming, and/or simulation taught at the undergraduate level. We were surprised that more of the programs did not require quantitative methods courses, given the opportunities for economic analytics in the job market and the strong expertise of AEAB faculty in these areas. Twenty-four percent of the programs required software courses, typically involving spreadsheets and/or other specific software applications. Overall, it appears that AEAB faculty consider calculus and statistics courses as core to the curriculum, with additional work in quantitative methods depending on the emphasis of the particular program.

\subsection{Policy, Trade, and Law Courses}

Relatively few programs (9\%) required a specific agricultural trade course, and $34 \%$ required a specific agricultural policy course. Only $50 \%$ of the curricula required any agricultural policy, trade, or international economics course. Most $A E A B$ programs offer courses in these areas, but most of these courses are offered as electives. In comparison, Boland and Akridge (2008b) found that about half of the AEAB curricula required an agricultural policy course.

Significant differences were found between AEAB programs in whether a law course was required. Although $29 \%$ of the agribusiness programs required a Business Law course, no agricultural economics program required such a course. Similarly, $31 \%$ of the agribusiness programs required an Agricultural 
Law course, but only $6 \%$ of the agricultural economics programs required such a course. Boland and Akridge (2008b) found that an Agricultural Law course was required by about $21 \%$ of agricultural economics and $24 \%$ of agribusiness curricula. Overall, $60 \%$ of agribusiness programs required any type of a business or agricultural law course, whereas only $6 \%$ of agricultural economics programs required such a course. Whether a specific law course is required depends significantly on whether the program is an agricultural economics or an agribusiness program.

\subsection{Accounting and Finance Courses}

Ninety-three percent of the programs required a first-semester accounting course, and $52 \%$ required a second semester of accounting. Significant differences were not found in accounting requirements between AEAB curricula. This suggests that the $\mathrm{AEAB}$ profession generally agrees that one semester of accounting is core to AEAB. There appears to be disagreement as to whether a full year of accounting is core to the curriculum.

Twenty-four percent, $31 \%$, and $9 \%$ of the programs required Agribusiness Finance, Agricultural Finance, and Financial Management courses, respectively. Although the percentages of agribusiness programs requiring these courses were numerically greater than for agricultural economics programs, there is insufficient statistical evidence to suggest differences in proportions. A finance course offered by a college or school of business was required by $20 \%$ of the agribusiness and none of the agricultural economics program. Most $(85 \%)$ of the agribusiness programs required some type of a finance course, whereas only $35 \%$ of the agricultural economics programs required such a course; the difference in proportions was highly significant $(P \leq 0.01)$. It appears finance is generally considered core for agribusiness, but not agricultural economics programs. Boland and Akridge (2008b) found that about two-thirds of AEAB programs required an Agricultural Finance course in 2003.

\subsection{Management Courses}

We examined five specific management courses: a business school management course, Agribusiness Management, Farm Management, Strategic Management, and Supply Chain Management. The first three were more likely to be required by agribusiness than agricultural economics programs, with 24- to 28-point spreads for all three. None, however, appear to be considered core to either program, with Agribusiness Management being the most likely to be required by agribusiness programs, at $63 \%$. In comparison, almost two-thirds of the agribusiness programs analyzed by Boland and Akridge (2008b) required Agribusiness Management, roughly the same proportion as they found for agricultural economics programs. However, the requirement of any management course appears to be considered "core" for agribusiness programs, with $91 \%$ of the programs requiring some type of a management course. On the other 
hand, there seems to be disagreement as to whether a management course should be core to agricultural economics programs: $53 \%$ of these programs required a management course. Management courses can vary widely in content, as discussed by Boland and Akridge (2008a).

\subsection{Agricultural Prices and Marketing Courses}

Relatively few programs (22\%) required a specific Agricultural Prices course (compared with $40 \%$ of AEAB programs as shown in the Boland and Akridge [2008b] study), though some programs may consider Agricultural Prices and Intermediate Microeconomics as close substitutes. On the other hand, most $(86 \%)$ required any type of a marketing course, with $97 \%$ of the agribusiness programs and $71 \%$ of the agricultural economics programs requiring one. The difference in proportions was significant at $P \leq 0.10$. Most programs $(67 \%)$ required an Agricultural Marketing course, while $17 \%$ required an Agribusiness Marketing course. It is recognized that for some cases, these courses are likely synonymous, but in other cases could differ in focus, with Agricultural Marketing focusing more heavily on farm-level marketing and Agribusiness Marketing focusing more heavily on marketing functions downstream from the farm firm. Boland and Akridge (2008b) also found that most AEAB programs required an Agricultural Marketing course. Agribusiness programs were more likely to require a business school marketing course than agricultural economics programs. Twenty-five percent and $7 \%$ of the programs required Agricultural Market Structure and Commodity Marketing courses, respectively. The requirement of a marketing course seems to be "core" to agribusiness programs, and the majority of agricultural economics programs also appear to consider such a course as "core."

\subsection{Other Coursework}

Seven percent of the programs required any type of a development economics course, with equal portions of the AEAB programs requiring such a course. Twenty-six percent of the programs required a resource or environmental economics course, with Resource Economics being the more common. Although the percentage of agricultural economics programs $(35 \%)$ requiring such a course was numerically higher than for agribusiness programs $(20 \%)$, the difference was not statistically significant. With increased environmental and natural resource policy issues facing agriculture, it can be argued this is an area where AEAB students need exposure.

Considering the importance employers of $\mathrm{AEAB}$ graduates appear to be placing on "soft skills" such as oral and written communication skills (Litzenberg and Schneider, 1987; NFAMEC, 2004; Noel and Qenani, 2013), we were surprised that only about half of the programs required any type of a professional writing or public speaking/communications course. Although numerically higher percentages of agribusiness programs required these courses, the differences were 
statistically nonsignificant. At some universities, there is insufficient instructional capacity in English and/or communications departments to meet the demands of such courses, so that could be affecting the percentages requiring these courses. In some programs, writing and oral communication skills are addressed via departmental course offerings. Based on our observations of student communication skills and what employers are telling us about the importance of these skills, we urge faculty in programs that provide little training in these areas to consider ways to ensure student proficiency in communications.

Only $58 \%$ of AEAB programs required technical agriculture courses such as Agronomy, Animal Science, Food Science, and so forth, which have traditionally been service courses offered by other college of agriculture departments. The average program required 5.1 hours of such courses, with the highest number of required hours in this category being 21 . This is lower than that found by Litzenberg, Gorman, and Schneider (1983) and later Harris, Miller, and Wells (2003). For $43 \%$ of the programs, we could not identify a required course that we would categorize as a "technical agriculture" course. The reduction and in some cases deletion of such courses has likely been the result of increases in business-type courses in agribusiness curricula, greater emphasis on post-farm gate agriculture, and pressure on universities to reduce curriculum hours to promote higher 4-year graduation rates. Although employers have placed technical agriculture knowledge rather low on the attribute set of AEAB graduates, such courses provide context for many of the decisions AEAB graduates make. Basic knowledge of agricultural production is particularly important for the increasing portion of AEAB graduates with limited agricultural backgrounds.

\section{Observations}

\subsection{Agricultural Economics and Agribusiness Degrees Do Not Have Strong Name Recognition}

Anyone who has majored in agricultural economics or agribusiness has been asked, What does one study in your major and what type of a job would a person in your major typically take? There are likely a number of reasons for low name recognition in AEAB. Espey and Boys (2015) found that $<20 \%$ of high school students could name a job other than farming that an agricultural economics graduate might secure. Although farming is a career AEAB graduates may enter, it is but one of many. Misconceptions can continue at the college level with students not fully recognizing the potential of an AEAB degree. Many programs accept most of their students during the sophomore and junior years of their undergraduate studies.

There are only $106 \mathrm{AEAB}$ programs at state universities and few if any remaining at private universities. There are, however, well over 600 state 
4-year colleges and universities in the United States and many more private institutions. Of the $106 \mathrm{AEAB}$ programs, there is a wide array of names used for the degrees. Of the 58 programs we examined, the degrees had 21 different names, with the top 3 names being agribusiness, agricultural economics, and agricultural business. Not only does the AEAB profession have relatively small numbers of programs granting these degrees, but they are called by 21 different names.

How is the wide range of degree names in AEAB affecting our branding and degree visibility? To compare with other fields, we examined economics, marketing, management, biology, and agronomy-related majors at each of the land grant universities included in our study. Similar to our analysis of AEAB programs, we visited the websites of each of these programs to determine their program names. For most universities, the economics, marketing, and management degrees conferred do not divert much from the disciplinary name. Main variations include business administration, general business, and business economics, which are most commonly seen when the major is housed in the business school. For biology degrees, name recognition is quite high; the degree name most commonly used is biological sciences. ${ }^{14}$ For agronomy majors, we observe the most variability in the discipline and name of degree conferred. Some of the most common names were agronomy and soils, sustainable plant systems, plant sciences, crop science, soil and crop science, and agronomic sciences. Of the five majors, those with the greatest consistency of degree name are also those available at most comprehensive universities: business-related and biology. Agronomy, however, like AEAB, is available at a limited number of comprehensive universities and has a wide array of names. Thus, in addition to having limited offerings, the agriculture degree names vary significantly, potentially further exacerbating the problem of major name recognition. Do adjectives such as "food," "resource," "development," "applied," and others attract more students than the standard AEAB names? Although there could be differences in perceptions by region and/or university, this is an area of investigation that could produce some potentially interesting results for the AEAB profession.

\subsection{Standard Coursework Required of Agricultural Economics and Agribusiness Students}

It is evident from our study that about six courses universally make up the core for AEAB programs: Principles of Microeconomics, Principles of Macroeconomics, Intermediate Microeconomic Theory, Accounting I, Calculus I, and Statistics. Otherwise, there is wide variation in what agricultural economists believe should make up the core AEAB coursework. This wide variation was previously recognized by Boland and Akridge (2004) with regard to

14 Under "biological sciences” we also tend to see microbiology, marine biology, and zoology majors. 
agribusiness programs. They called for professional organizations to become involved in developing model agribusiness programs that would suggest some standard coursework while providing individual universities some flexibility to develop curricula that uniquely serve the industries and environments in which they work.

Agribusiness curricula are more extensively structured than agricultural economics curricula, with agricultural economics curricula more likely to allow students to choose from lists of courses. Courses more likely to be required in agribusiness than in agricultural economics programs include: Agricultural or Business Law; Agricultural, Agribusiness, or general Finance; Agricultural, Agribusiness, or general Marketing; and Agricultural, Agribusiness, or general Management. Courses in finance, management, and marketing are generally considered as core to agribusiness programs, with $\geq 85 \%$ of agribusiness programs requiring courses in each of these areas. They are not, however, universally considered as core to agricultural economics programs. Thus, the main difference we observe between agricultural economics versus agribusiness programs is the greater emphasis on business courses of all types in the agribusiness category. Generally, however, large differences between the two are not found, as was also established by Boland and Akridge (2008b).

Most programs include rather extensive "choose from a list" agricultural economics and business courses. Although employers can generally expect AEAB graduates to be well versed in the economic and business aspects of agriculture, it appears that the university from which students graduate can significantly affect their knowledge in certain areas. For instance, if students hold degrees from one of the roughly half of agricultural economics programs that do not require a management course, there is no guarantee these students will have been exposed to the basic tenets of management.

There is some question as to which courses should be offered "in-house" by AEAB faculty versus via others, such as through colleges of business. Although we cannot provide definitive answers to what "should be," we can provide information on how the 58 programs we examined are handling this, specifically for business-oriented coursework. Of the $86 \%$ of AEAB programs requiring any type of marketing course, only 3 of the 50 did not require at least one of the required marketing courses to be an agricultural marketing-related course. Of the $81 \%$ of $\mathrm{AEAB}$ programs requiring any type of management course, only 6 of the 47 did not require at least one of the required management courses to be an agricultural or farm-related management course. Of the $71 \%$ of AEAB programs that required a finance course, only 4 of the 41 programs did not require at least one of the required finance courses to be an agricultural finance-related course. It appears that most of the AEAB programs that require such courses prefer these courses to include agricultural business content. In some areas, such as agribusiness management, it has become challenging to find new $\mathrm{Ph}$. D. graduates with expertise in this area. 


\section{3. "Soft Skills"}

As discussed earlier, employers of AEAB graduates tend to emphasize the importance of "soft skills" such as communication, team building, and so forth, in their employees (Litzenberg and Schneider, 1987; NFAMEC, 2004; Noel and Qenani, 2013). This suggests that specific courses in written and oral communications, ethics, and others would be important for AEAB students. However, our results do not suggest that dedicated courses are necessarily included in AEAB curricula. It is likely that there is insufficient capacity to service the demand for such courses that are offered by English, speech communications, and other departments at some universities. In such cases, how can AEAB programs best incorporate the development of such skills into the curriculum, and in some cases within existing AEAB courses? Employer survey results suggest the need to find ways to ensure AEAB students have ample opportunities to develop these skills in college, hence the need to evaluate programs to ensure students develop these skills.

There are a number of experiential learning opportunities that most universities offer to encourage the development of "soft skills." One program requires experiential/interdisciplinary learning experiences such as internships, study abroad, and undergraduate research, where the students have a choice of several options for fulfilling the requirement. Although internships are available through many of the programs, only two programs required internships. Internships not only allow students to develop workplace skills, including "soft skills," but also are a way through which students can "connect with industry," as discussed by Akridge (2016). Marsh et al. (2016) discuss how research internships, which combine the internship experience with undergraduate research, benefit students in a number of ways, including improved communication and critical thinking skills. Boland (2009) noted that colleges of agriculture at many universities are leaders in study abroad programs; these programs may provide additional resources for AEAB students to have an experiential learning experience that can enhance "soft skills." Note that culture/gender awareness/sensitivity was in the top five skills, abilities, and experience employers desired as reported by NFAMEC (2004). Study abroad programs provide an outlet for students to develop a more global view and appreciation for diversity, intercultural awareness, and understanding (Harrell et al., 2017; Miller, 1993). These programs thus contribute to meeting employer expectations (Harrell et al., 2017), as well as to the student learning outcomes expected by many universities.

\subsection{Quantitative Methods}

A strength of most agricultural economists is their expertise in quantitative analytical skills. Many agricultural economists work extensively with economic and business data to address timely issues as requested by clientele. Thus, AEAB 
faculty are in a strong position to offer undergraduates unique data analytics training through courses such as applied econometrics and linear programming. There is a large gap between many existing AEAB undergraduate and graduate programs in terms of analytics, with some undergraduate programs offering little or no quantitative analytic training, whereas graduate programs tend to focus more heavily on these skills. Although undergraduate AEAB students may never fully utilize these quantitative skills in their careers, they are likely to use results of analyses produced using these methods, conducted by other business analysts. For these students, courses in these areas can increase their appreciation for the assumptions behind the analyses, enhancing their ability to fully interpret the results. Other students will develop strong interest in analytical tools and pursue further training to become business analysts or enter graduate programs in agricultural economics.

Just over half of $A E A B$ undergraduate programs require quantitative methods courses. Is the AEAB profession missing an opportunity to brand its graduates not only in terms of their expertise in the business of agriculture, but also as strong entry-level quantitative analysts? A couple of courses in econometrics and operations research at the undergraduate level could open new opportunities for AEAB students, and agricultural economics faculty members are well qualified to teach those courses. Such courses could form the basis for developing an area of concentration in quantitative methods.

\subsection{Areas of Concentration}

There is evidently a diversity of thought on the value of areas of concentration. The majority of AEAB undergraduate programs do not offer them, whereas others offer quite a few, with one program offering 15 . With an area of concentration, students can highlight a particular area of expertise for their targeted area of employment. If ample free electives are available to use toward an area of concentration, then opting for one requires little or no additional coursework. On the other hand, Hurley and Cai (2012) present an argument for a more flexible curriculum without areas of concentration, suggesting this motivates students to identify interests and a career path early on and provides flexibility for selecting coursework that fits their specific career path. We see value in both approaches, but urge undergraduate committees to be careful to ensure that curricula are structured enough to ensure competencies in the core areas.

To compare AEAB program use of areas of concentration with their use in other majors, we examined area-of-concentration offerings in economics, marketing, management, biology, and agronomy curricula using the same land grant institutions as used in the earlier analysis. This involved again visiting the websites of these programs to determine their areas of concentration. Areas of concentration, tracks, or specializations are rather uncommon in economics and marketing programs. We tend to see greater use of areas of concentration in management programs with the main areas of concentration being human 
resource management, small business and entrepreneurship, and operations and supply chain management. ${ }^{15}$ In biology programs, we observe a number of concentrations in ecology, evolution and conservation biology, botany, and teaching tracks. The greatest variety of areas of concentration was found in agronomy, such as business and industry, consulting and production, plant science and biotechnology, precision agriculture, range management, soil and environmental science, pest management, turf grass, and horticultural science.

A couple of areas of concentration stand out as potential opportunities for recruitment. Four land grant programs offered pre-law areas of concentration. With significant numbers of students desiring law school postgraduation, this seems a good way to attract strong students into the program, particularly those with an interest in business and/or agricultural law. ${ }^{16}$ Three programs offered pre-vet areas of concentration. This could be another good way to attract top students into AEAB. Many veterinarians need to understand basic business concepts, particularly those who own veterinary clinics, and colleges of veterinary medicine generally do not offer those courses. The Association of American Veterinary Medical Colleges (2017) discusses a number of attributes veterinary colleges are looking for in applicants, with one being knowing "how to run a business." Fitting such an area of concentration into an agricultural economics or agribusiness curriculum may in some cases prove challenging, particularly given the core set of courses required by most colleges of veterinary medicine for admission. Given, however, the relatively low percentage of undergraduates who plan to attend veterinary school, but who never end up attending because of change of plans or rejection, completion of a degree with strong employment prospects such as agricultural economics or agribusiness has advantages.

\section{Summarizing}

$\mathrm{AEAB}$ student numbers have been increasing in recent years following declining numbers in the 1980s. We do not predict that employer demand for AEAB graduates will decrease in the foreseeable future, as most AEAB graduates have training in economics, management, marketing, team building, speaking, writing, and technical agriculture. Faculty do, however, need to continue to review and adjust curricula to changes in agriculture and the food industry, responding to employer needs. Considering that most of the U.S. dollars spent for food go to the marketing function, with new products continually being introduced, significant teaching efforts need to focus on the value-added agribusiness sector. $\mathrm{AEAB}$ curricula need to ensure that graduates are well versed in marketing,

15 We noted that if the department offers a single major in management, students have the opportunity to select an area of concentration. In the case of multiple majors, the areas of concentration tend to be minimal.

16 A similar pattern is observed in economics and management majors. 
management, finance, and economics, and that they have the analytical and "soft skills" needed to be successful in the business sector. Though we believe concentrating on the value-added agribusiness sector makes sense, we also think a good understanding of technical agriculture is helpful to graduates-this is an attribute that sets AEAB students apart from general business students. We also urge the profession to consider agricultural economists' advantages in data analytics and quantitative methods, and whether it makes sense as a profession to introduce or include more of that content into AEAB undergraduate programs.

One of our observations in conducting this analysis was the wide variations in course requirements by program. Although some variation is expected depending on university strengths and regional agribusiness industries, some consistency is warranted if the $\mathrm{AEAB}$ profession desires greater recognition by industry for the skill sets of its graduates. This provides an opportunity for AEAB professional organizations to become involved in dialogue on expected learning outcomes for AEAB majors. Boland and Akridge (2004, p. 576) suggested that $A E A B$ professional organizations "should develop a suggested set of courses and experiences that would constitute an agribusiness degree," so the idea is not new.

Agricultural economists are increasingly challenged to inform the public about the value of AEAB degree programs. A success story in agriculture is that it takes fewer and fewer farmers to feed the world population, hence agriculture is more efficient. A downside of that story, however, is that fewer and fewer people are engaged in production agriculture or know much about it, so knowledge of the marketable degrees that colleges of agriculture offer, particularly in AEAB, may be decreasing. The AEAB profession needs to be informing high school students and students entering college of the opportunities available in AEAB. AEAB programs generally offer well-rounded degrees, but they seem to remain a rather well-kept secret.

We believe there are a number of areas of future research that would be helpful in this area-we list five here that we think would be particularly helpful and/or interesting. First, it would be of interest to examine the population of AEAB programs, including those at non-land grant and private universities. There are several AEAB undergraduate programs at non-land grant universities that are quite large and successful, and information on those programs would increase our knowledge about AEAB program structure and allow for comparisons of programs by university type (land grant, non-land grant state, and private). Second, it would be of interest to examine how professional organizations could coordinate the development of recommended AEAB coursework for greater consistency, and to examine how greater consistency in coursework could be expected to affect employer demand for AEAB graduates. Third, an area that we did not address is minors in AEAB. Minors provide non-AEAB majors the opportunity to gain knowledge of the economics and business of agriculture and increase the demand for AEAB courses. Enhanced understanding of how these minors are constructed and how they affect employment would be useful. Finally, 
a couple of the reviewers mentioned that industries included in the state in which the university is located could affect coursework, names of AEAB programs, and/or areas of concentration offered. We believe a study examining the impact of industry (i.e., percentage of employment in agriculture, food processing, etc.) on curricula could provide significant insight as to why curricula vary by university.

\section{References}

Adrian, J. "Undergraduate Education in Departments of Agricultural Economics in the South: Status, Challenges, and Opportunities." Southern Journal of Agricultural Economics 21,1(1990):1-9.

Akridge, J. "Steering the Best Talent towards Colleges of Agriculture." Paper presented at the 2016 USDA Agricultural Outlook Forum, Arlington, VA, February 25, 2016.

Association of American Veterinary Medical Colleges. "Media Frequently Asked Questions." Internet site: http://aavmc.org/Media-FAQs.aspx (Accessed May 22, 2017).

Bampasidou, M., K. Grogan, J. Clark, and M. Sandberg. "Career Skills: Perceptions of Importance and High Impact Learning Activities for Skill Development in Agricultural Economics and Agribusiness Programs." NACTA Journal 60,1a (2016):36-42.

Boland, M., and J. Akridge. "Introductory and Advanced Agribusiness Management Courses and Food Business Courses in Undergraduate Agribusiness Programs.” Working Paper No. 4, National Food and Agribusiness Management Education Commission, West Lafayette, IN: Purdue University; and Manhattan: Kansas State University, 2008a.

- "A Summary of Undergraduate Curriculum in Agribusiness Management Degrees." Working Paper No. 1, National Food and Agribusiness Management Education Commission, West Lafayette, IN: Purdue University; and Manhattan: Kansas State University, 2008b.

Boland, M., E. Lehman, and J. Stroade. "A Comparison of Curriculum in Baccalaureate Degree Programs in Agribusiness Management." International Food and Agribusiness Management Review 4,3(2001):225-35.

Boland, M.A. "Leadership Development in Agricultural Economics: Challenges for Academic Units." Journal of Agricultural and Resource Economics 34,3(2009):367-82.

Boland, M.A., and J. Akridge. "Undergraduate Agribusiness Programs: Focus or Falter?" Review of Agricultural Economics 26,4(2004):564-78.

Carnevale, A.P., B. Cheah, and A.R. Hanson. "The Economic Value of College Majors." Georgetown Center on Education and the Workforce, 2015. Internet site: https://cew. Georgetown.edu/cew-reports/valueofcollegemajors/ (Accessed June 30, 2016).

Carnevale, A.P., J. Strohl, and M. Melton. What's It Worth? The Economic Value of College Majors. Georgetown Center on Education and the Workforce, 2011. Internet site: https://cew.Georgetown.edu/wp-content/uploads/2014/11/whatsitworth-complete.pdf (Accessed June 30, 2016).

Colbath, S.A., and D.G. Morrish. "An Analysis of the Spatial Effects of Population Density on the Agricultural Knowledge of College Freshmen." NACTA Journal 54,4(2010):11-15.

Dale, C., J.S. Robinson, and M.C. Edwards. "An Assessment of the Agricultural Literacy of Incoming Freshmen at a Land-Grant University.” NACTA Journal 61,1(2017):7-13.

Espey, M., and K.A. Boys. "Alignment of Effort: Recruitment into Undergraduate Agricultural and Applied Economics Programs." Journal of Agricultural and Applied Economics 43,3(2015):382-410. 
Graham, D.L. "Employer Perception of the Preparation of Agricultural and Extension Education Graduates.” Journal of Southern Agricultural Economic Research 51,1(2001):89101.

Hamilton, L., R.W. Grant, M. McGarry Wolf, and L.G. Mathews. "The Value of Undergraduate Research: A Study of Agribusiness Alumni Perceptions." NACTA Journal 60,2(2016):207-12.

Harrell, A., G. Sterner, T.R. Alter, and J. Lonie. "Student Perceptions of the Impact of Their Diverse Study Abroad Experiences.” NACTA Journal 61,1(2017):56-65.

Harris, H.M., S.E. Miller, and G.J. Wells. "Undergraduate Curricula in Agribusiness and Agricultural Economics: What's the Difference?” Paper presented at the Annual Meeting of the Southern Agricultural Economics Association, Mobile, AL, February 1-5, 2003.

Heiman, A., J. Miranowski, D. Zilberman, and J. Alix. "The Increasing Role of Agribusiness in Agricultural Economics.” Journal of Agribusiness 20,1(2002):1-30.

Hurley, S.P., and X. Cai. "A Dynamic and Flexible Undergraduate Curriculum: Preparing Agribusiness Students for a Continually Changing Career." International Food and Agribusiness Management Review 15,A(2012):37-41.

Larson, R.B. "Changing Emphasis in Agribusiness Curricula." Journal of Food Distribution Research 27,1(1996):30-37.

Litzenberg, K.K., W.D. Gorman, and V.E. Schneider. "Academic and Professional Programs in Agribusiness.” American Journal of Agricultural Economics 65,5(1983):1060-64.

Litzenberg, K.K., and V.E. Schneider. "Competencies and Qualities of Agricultural Economics Graduates Sought by Agribusiness Employers.” American Journal of Agricultural Economics 69,5(1987):1031-36.

Louisiana State University. “2020 Flagship Agenda Goals.” Internet site: http://www.lsu.edu/ flagshipagenda/goals2020.shtml (Accessed May 22, 2017).

Marsh, L.E., F.M. Hashem, C.P. Cotton, A.L. Allen, B. Min, and M. Clarke. "Research Internships: A Useful Experience for Honing Soft and Disciplinary Skills of Agricultural Majors. NACTA Journal 60,4(2016):379-84.

Miller, E.J. "Culture Shock: A Student's Perspective of Study Abroad and the Importance of Promoting Study Abroad Programs.” Washington, DC: Department of Education, Education Resources Information Center (ERIC), ERIC No. ED358492, 1993.

National Association of Colleges and Employers. "Job Outlook 2016: The Attributes Employers Want to See on New College Graduates' Resumes.” Internet site: http://www. naceweb.org/s11182015/employers-look-for-in-new-hires.aspx (Accessed November 21, 2016).

National Center for Education Statistics. "Digest of Education Statistics.” 2014. Internet site: http://nces.ed.gov/programs/digest/d14/tables/dt14_303.70.asp (Accessed May 24, 2016).

National Food and Agribusiness Management Education Commission. National Food and Agribusiness Management Education Commission: Industry Steering Committee-Primary Themes from Interview Responses. Final Summary July 31, 2004. Internet site: http://www.farmfoundation.org/news/articlefiles/ 1016-2isc-executivesummary-final73104_2_2_.pdf (Accessed July 15, 2016).

Noel, J., and E. Qenani. "New Age, New Learners, New Skills: What Skills Do Agribusiness Graduates Need to Succeed in the Knowledge Economy?" International Food and Agribusiness Management Review 16,3(2013):17-36.

Oliff, P., V. Palacios, I. Johnson, and M. Leachman. "Recent Deep State Higher Education Cuts May Harm Students and the Economy for Years to Come.” Research Report, 
Center on Budget and Policy Priorities, March 19, 2013. Internet site: http://www.cbpp. org/research/recent-deep-state-higher-education-cuts-may-harm-students-and-theeconomy-for-years-to-come (Accessed March 24, 2017).

Perry, G.M. "What Is the Future of Agricultural Economics Departments and the Agricultural and Applied Economics Association?" Applied Economic Perspectives and Policy 32,1(2010):117-34.

Riesenberg, L.E. "Graduate's Recommendations: Future Curriculum Emphasis for Colleges.” NACTA Journal 32,2(1988):34-37.

Scanlon, D.C., T.H. Bruening, and A. Cordero. “An Industry Perspective on Changes Needed in Agricultural Education Curricula." Journal of Agricultural Education 37,2(1996):1723.

Smith, M.F. "Curricular Changes for Colleges in Agriculture: Student Perceptions and Future Trends.” NACTA Journal 33,2(1989):17-20.

U.S. Department of Agriculture. "Food and Agricultural Education Information System." Internet site: http://faeis.ag.vt.edu/faeisr.cfm (Accessed June 29, 2016).

U.S. Department of Agriculture, Economic Research Service. "Price Spreads from Farm to Consumer: Summary Findings.” Internet site: http://www.ers.usda.gov/data-products/ price-spreads-from-farm-to-consumer/summary-findings.aspx (Accessed May 31, 2016).

Wysocki, A.F., G.F. Fairchild, R.N. Weldon, A.W. Biere, J.R. Fulton, and C.S. McIntosh. "Agricultural, Agribusiness, and International Marketing Courses in Undergraduate Curricula: Issues and Ideas.” Journal of Agribusiness 21,2(2003):197-212.

Zar, J.H. Biostatistical Analysis. 2nd ed. Englewood Cliffs, NJ: Prentice-Hall, 1984. 